\title{
吸収マルコフ連鎖を用いた観測交通量からの OD推計法に関する研究
}

\author{
高山純一 1 ・杉山智美 2 \\ 1正会員 工博 金沢大学助教授 工学部土木建設工学科 (广920 石川県金沢市小立野2-40-20) \\ 学生会員 金沢大学大学院 工学研究科土木建設工学専攻(T920 石川県金沢市小立野2-40-20)
}

\begin{abstract}
都市内の限定された地域を対象として, 対象地域内で観測される道路区間交通量と交差点での右左折直 進交通比率から，吸収マルコフ連銷モデルを応用してOD交通量を推計する方法を考える。この方法では, 交差点での右左折直進比率などから吸収マルコフモデルのOD遷移確率を与えれば，未知変量は発生交通 量のみとなる．そこで，近年，組み合わせ最適化問題の解法として注目される遺伝的アルゴリズム (GA) を利用して未知である発生交通量を与える方法を提案する.

本研究では，発生交通量のみを未知変量とする既存の推計法と比較することによって，この推計法の収 束性を検討する. また, 東京駅周辺の主要交差点における実測データを利用して, その適用性の検討を行 う.
\end{abstract}

Key Words : observed link flows, Absorbing Markov Chain, Genetic Algorithum

\section{1.はじめに}

都市内のある特定地域において，交通規制の見直 しや信号制御の最適化を行うためには，対象とする 地域の現状OD交通量を詳細に把握することが不可 欠である。しかし，従来のパーソントリップ調查を 基本としたマクロなOD推計モデルでは, 都市圈全 体を対象とするような場合には有効であるが，都市 内の限定された狭い地域を対象とする場合には推計 精度上限界のある場合が多い。また，ビデオ撮影に よるナンバープレートマッチング法では，調查費用

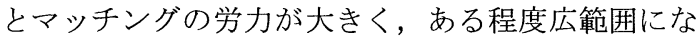
るとマッチングミスによる精度への影響も大きい，

このような場合，実測の道路区間交通量から対象 地域内の O D 交通量を推計する方法が有効であり， 従来からいくつかの方法 ${ }^{1) \sim 8)}$ が提案されている. しかし，これらの方法においても，(1)経路選択率が

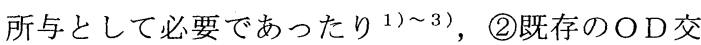

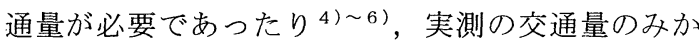
らOD推計を行うモデル7)，8)は少ないようである.

また，この実測交通量からのOD推計法において も，従来の方法の多くが都市圈全体を対象としたモ

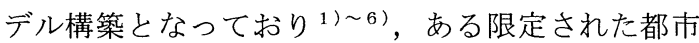
地域を対象とした推計モデル ${ }^{71,8)}$ は少ない.

そこで，本研究ではそれほど費用がかからず，し
かも手軽に推計が行える簡便なO D 推計法を提案す る. この方法は, 具体的には対象地域内の道路区間 上で観測される実測交通量と交差点での右左折直進 比率から吸収マルコフ連鎖モデルを応用してOD交 通量を推計する方法(「GAマルコフOD推計モデ ル」と呼ぶ)である。ここでは，収束性についての 検討ならびに東京駅周辺の主要交差点における観測 データを用いた提案モデルの適用性の検討を行う。

\section{2. 街路のモデル化と吸収マルコフ連鎖 モデル}

一般街路の自動車交通流をマクロな視野で眺めた 場合，交通流は交差点で 1 つの確率に従って方向を 変え, 次の交差点に向かって流れていく. そして, その交差点でまた別の確率に従って方向を変えて流 れていくように観察される。このような状況を定式 化したのが，佐佐木の吸収マルコフモデル ${ }^{9)}$ である. そこで，ここでは一般街路を次のようにモデル化し， OD交通量の推計モデルとして利用する.

まず，本研究では対象地域をいくつかのゾーンに 区分し，各々のゾーンにそれぞれ一対の発生源 (○：発生ノード) と吸収源 $($ : 集中ノード $)$ を設定 する. 図-1 は主要交差点数が 4 つの場合を例とし て示したものであるが，ゾーン区分の仕方によって 


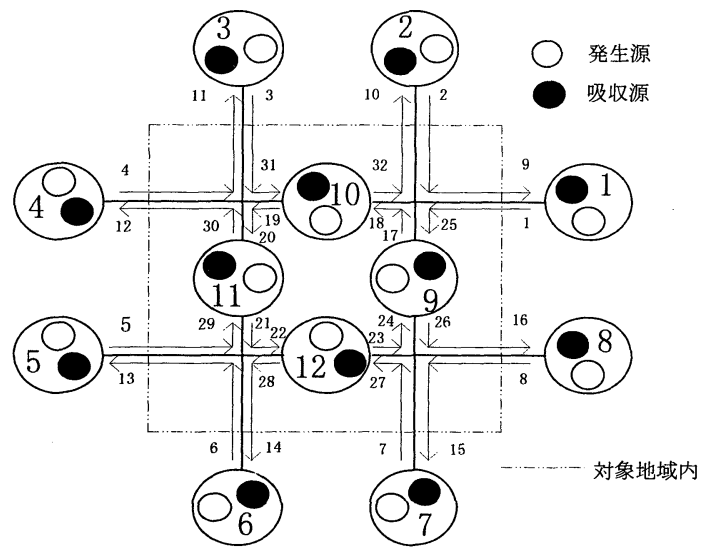

図-1 対象地域のゾーニングと街路のモデル化

交差点に発生・吸収源を設定する場合と道路区間上 に設定する場合の 2 通りが考光られる。ここでは, 交差点付近で発生・吸収される交通流は少ないもの と考え，道路区間上に発生・吸収源のノード(図-1 ではノード(9)〜(12) を設定した。 また，対象地域外 からの交通に対しては対象道路網の周辺部道路 (対 象地域の境界線上の道路)にその背後地を代表とす る発生源と吸収源を設定する. 図-1 では(1)〜8)の ノードに対応する。

いま，対象地域内のノードおよび対象地域外との 境界道路上に存在するノードを合わせて $\mathrm{r}$ 個のノー ドが存在するものとする. そして，それぞれのノー ドには一対の発生源と吸収源が存在し, 対象地域内 の交差点と道路区間上のノードとの間あるいは対象 地域外ノードと対象地域内交差点とを結ぶ道路上の 過渡状態 (発生・吸収のない道路区間)の数を $\mathrm{s}$ 個と すると遷移確率行列 $P$ は式 (2.1)のように表される.

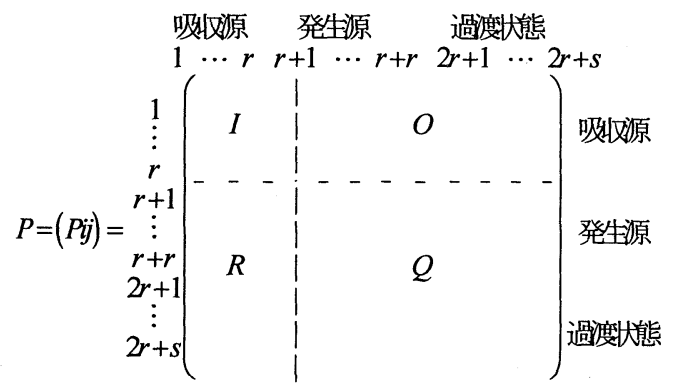

(2.1)

$R$ と $Q$ について, 発生源の性質 (発生源への他 の状態からの遷移はないということ）と，本モデル の構成型（本モデルでは, 発生源からの遷移は必ず
一度過渡状態を経過し, 直接吸収状態へ遷移しない ということ）を考慮に入れると，さらに式 (2.2)，(2.3)のように定義できる.
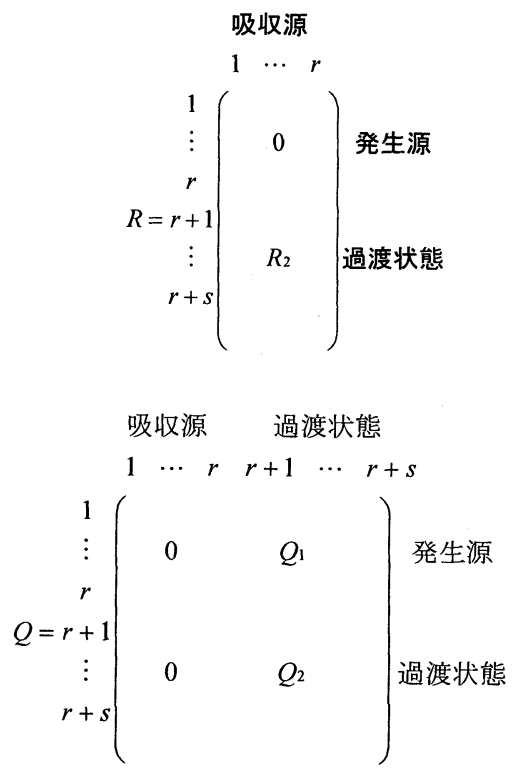

よって, 式(2.1) (2.2) (2.3)より

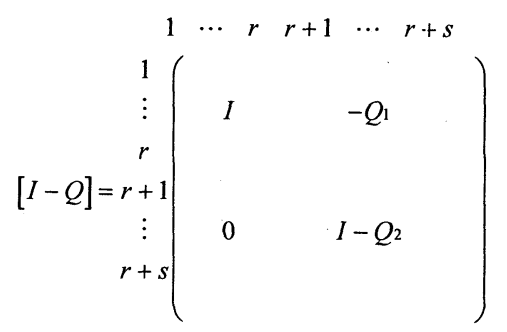

であるから, 基本行列 $[I-Q]^{-1}$ は次のようになる.

$$
\begin{array}{cccccc}
1 & \cdots & r & r+1 & \cdots & r+s \\
1 & & & \\
\vdots & & & & \\
r & & & Q_{1}\left[I-Q_{2}\right]^{-1} \\
{[I-Q]^{-1}=r+1} & & & \\
\vdots & 0 & & {\left[I-Q_{2}\right]^{-1}} \\
r+s & & & &
\end{array}
$$




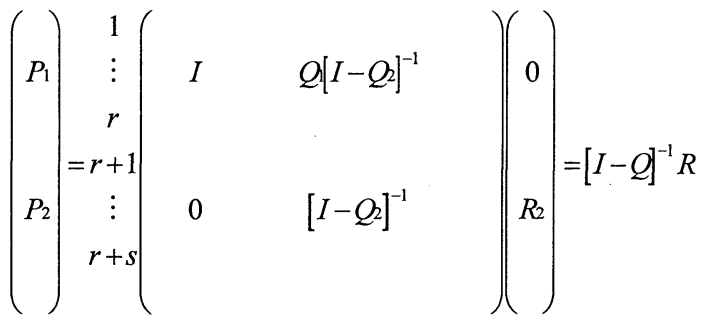

(2.6)

$$
\begin{gathered}
P_{1}=Q_{1}\left[I-Q_{2}\right]^{-1} R_{2} \\
P_{2}=\left[I-Q_{2}\right]^{-1} R_{2}
\end{gathered}
$$

$[I-Q]^{-1} R$ は $(r+s)$ 個の非吸収状態それぞれ から 1 台の車が発生した場合に, $\mathrm{r}$ 個の吸収状態そ れぞれに吸収される確率を示している。つまり， $P_{1}$ と発生交通量からそれぞれの吸収状態に吸収さ れる交通量が求められる.

また, 基本行列 $[I-Q]^{-1}$ は非吸収状態を出発し た 1 台の車が，それぞれの吸収状態を通過する回数 の期待值を示すものであるから，これと発生交通量 からで，それぞれの過渡状態を通過する交通量が求 められることになる.

ここで, 発生交通量を $v$ とすると, 吸収交通量 $u$ と道路区間交通量 $x$ が次の式により求められる.

$$
\begin{aligned}
& {[u]=[v] \cdot[I-Q]^{-1} R} \\
& {[x]=[v] Q_{1}\left[I-Q_{2}\right]^{-1}}
\end{aligned}
$$

\section{3. 遺伝的アルゴリズムを用いた簡易OD推計法}

一般に, 各ノードの発生交通量は未知であるが上 述のように何らかの方法により推定できれば，式 (2.7) ならびに式(2.8) より道路区間交通量とOD交 通量を推定することができる．したがって，この問 題を次のような最適化問題として定式化する.

$$
\text { 目的関数 } Z=\sum_{i}\left(R X_{i}-E X i\right)^{2} \rightarrow \min
$$

制約条件 式(2.6)

ただし，対象地域の境界線 (対象地域一の流入方 向）上で道路区間交通量が観測されておれば，それ が対象地域外ノード(周辺部ノード)の発生交通量と 一致するため, 対象地域内ノード(道路区間上)の交 通量のみが未知となる。なお，この問題は非線形の 最適化問題であるため, 次に示すような遺伝的アル ゴリズム $(\mathrm{G} \mathrm{A})^{10)}{ }^{11}$ により解くことを考える. (a) 未知変量の発生交通量を 2 進数の線列として コーディングし, ランダムに数組を発生させる.

(b) 各線列を発生交通量に変換したものと交差点分 岐確率などから推定される遷移確率行列を式 (2.6) 一代入し道路区間交通量 $\left(E X_{i}\right)$ を推定する.

(c) 道路区間交通量の実測値 $\left(R X_{i}\right)$ との残差平方和 $Z$ を式(3.1) より計算し, 逆数 $f$ を適応度とする.

$$
f=1 / Z
$$

(d) 適応関数が最大值 (道路区間交通量に関する残 差平方和の最小化)を取るまで ( a )から ( c )を繰り 返す.

ただし，（a）の線列を繰り返し発生させる過程に GAを適用する．そこで以下に， G A の定式化の具 体的な方法と収束条件を示す。

(1)適応関数と選択

一般に, 最適化の初期には適応関数の值がかなり ばらつき, 後期には適応関数の差が小さくなると考 えられる. そこで, 本研究では上記の式 (3.2)を用 い，以下のようなスケーリングを行い，式(3.3)を 適応関数とした。 なお, 選択の方法としては, ルー レット方式, ランキング方式, エリート方式, 期待 值による方法などがあるが, 本研究ではルーレット 方式を用いることにした.

$$
\begin{aligned}
& \frac{f^{\prime} \text { max }}{f^{\prime} \text { min }}=n \\
& f \text { max }-f: f \max -f \text { min }=f^{\prime}{ }_{\max }-f^{\prime}: f^{\prime} \text { max }-f^{\prime} \text { min } \\
& f^{\prime}=f \text { max }+\frac{\left(1-n^{-1}\right) f \text { max }}{f \text { max }-f \text { min }}(f-f \text { max }) \\
& f \text { max, } f \text { min : } f \text { の最大值および最小值 } \\
& f^{\prime} \text { max }, f^{\prime} \text { min }: f^{\prime} \text { の最大值および最小值 }
\end{aligned}
$$

\section{(2)交差と突然変異}

本研究では〈選択〉でルーレット方式を用いてい るので, 線列集合の並びには偶然性が伴っていると みなし，上下 2 線列での交差を行った．交差法には いくつかの方法が提案されているが, 本研究では 1 点交差法, または 2 点交差法を用いた。 また, 突然 変異については, 線列の 1 つのビットを任意に反転 させる方法を用いた，なお，その確率は交差確率よ りも低く設定される。

(3)収束条件

G A では, 必ずしも全ての線列が同じになるまで 計算を進める必要はなく, ある時点で計算を終了し, 


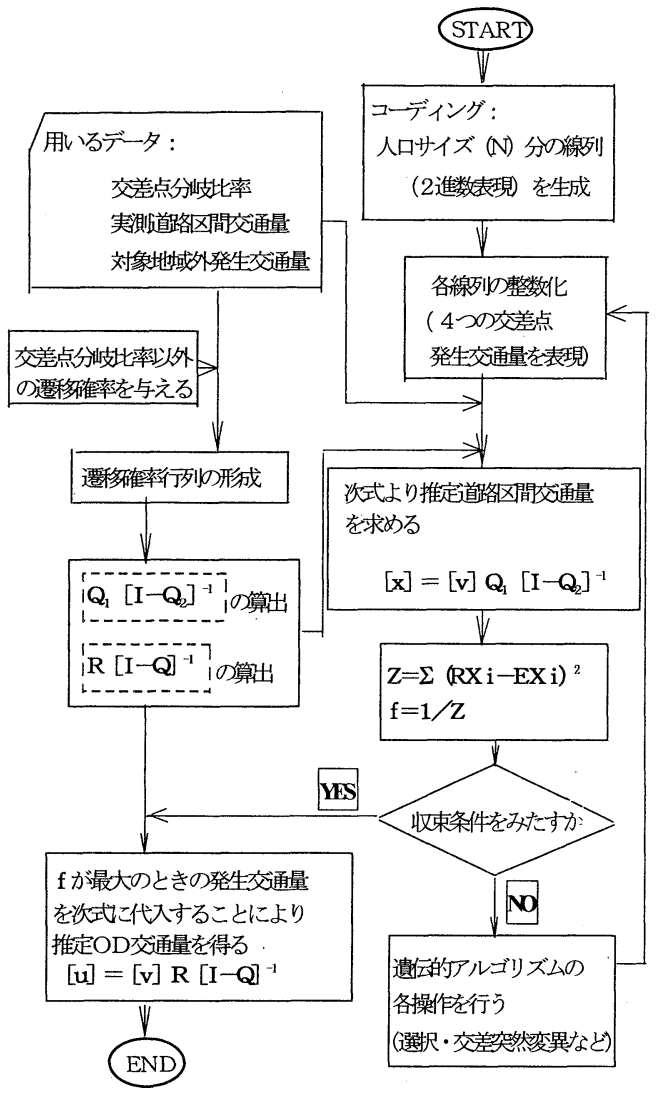

図-2 G A 法によるOD推計のフローチャート

さかのぼって最良の結果を得た線列を探すのが良い と考えられる. 本研究では，以下のいずれかの条件 が満足した場合に計算を終了させた.

(ア)最大世代数に達した場合

（イすべての線列が同じになった場合

（ウ）適応関数の最大值が以降の 20 世代で更新さ れない場合

\section{4. 解の収束性の検討}

\section{(1) OD推計の手順}

G A による解である発生交通量の妥当性を明らか にするために，図-1 で示した小規模な道路網を対 象としてモデルシミュレーションを行う。発生交通 量のみを推計する場合の既存の方法として，飯田の 発生交通量のみを未知変量とした実測交通量による 交通需要推計法2)がある。 その方法では，式(4.1) を用いて逐次修正を行っていくため，以下，「逐次

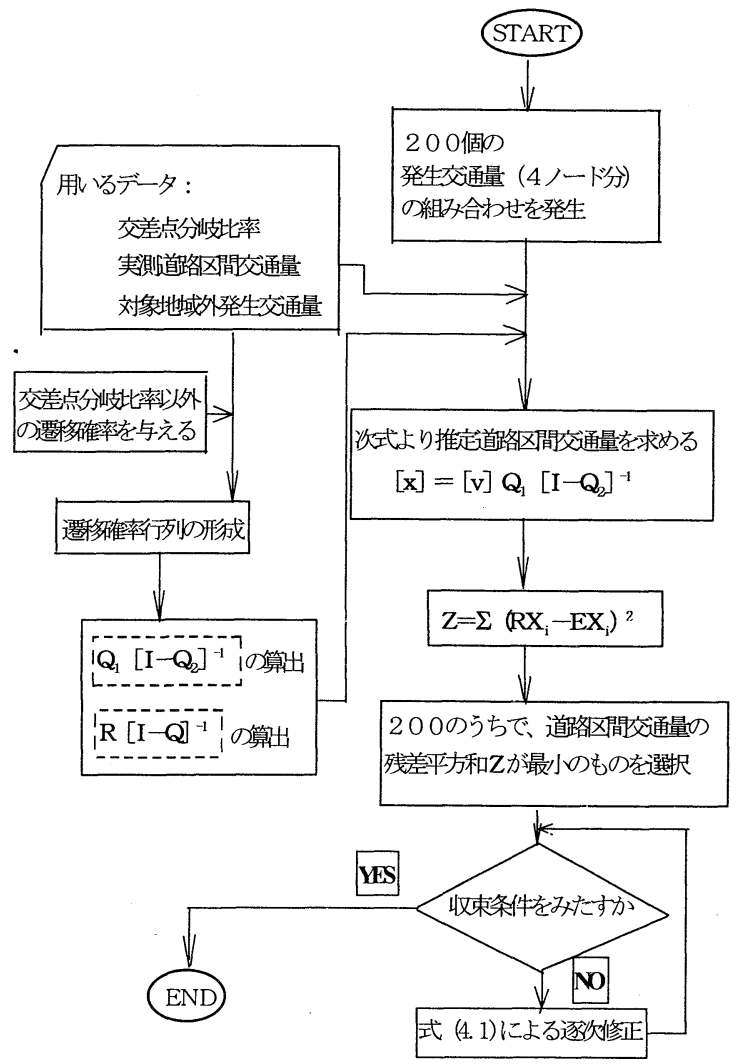

図-3 逐次修正法のフローチャート

修正法」と呼ぶこととする，本研究では，この逐次 修正法によって発生交通量を推計した場合と G Aを 用いて発生交通量を推計した場合について，推計さ れた解(発生交通量)の収束性を比較する.

\section{a) GAによる方法 (GA 法)}

発生交通量として, 最初に人口サイズ分 ( $\mathrm{N}$ パ ターン)を生成させ, 繁殖・淘汰, 交差, 突然変異 の操作を行う．交差，突然変異はあらかじめ与えた 確率以下で行うこととする．なお，最大世代数に達 したとき，全ての線列が同じになったとき，計算を 終了する.ここでは, $N=200$, 交差法は 2 種類, 交差確率は 3 種類, 突然変異確率は 2 種類設定する. 図-2にGA法を用いたOD推計の手順を示す.

\section{b) 逐次修正法}

ただし， $(q)$ は計算回数を表し，式(4.1)の右辺 第 1 項が 0 に十分近づくまで修正計算を行う.

なお，GAを用いる場合，発生交通量として最初 に人ロサイズ分 $(\mathrm{N}$ パターン)を生成させるため，逐 
: GA法

A : 逐次修正法

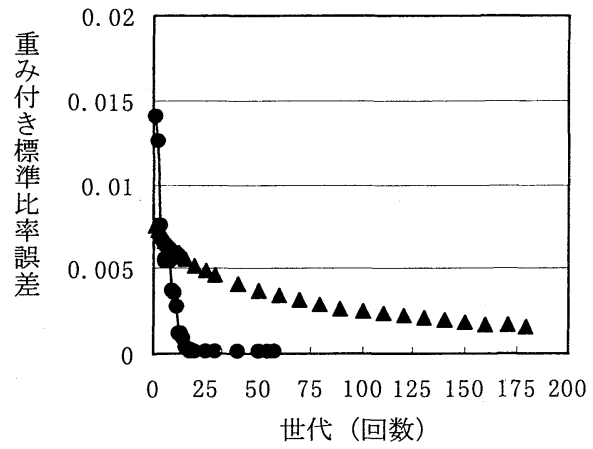

図-4 道路区間交通量の重み付き標準比率誤差

次修正による方法においても，同数 (Nパターン) 発 生させ，道路交通量の残差平方和が最も小さい 1 パ ターンについて逐次修正していく方法を用いた。 ま た, 発生交通量が与えられた後は, どちらの場合も 吸収文コフ連鎖の式(2.5) と式(2.6) を用いて推定 道路区間交通量とOD交通量を推計する。本研究で 用いた逐次修正法の手順を，図-3に示す.

$$
A i^{(q)}=\left(\sum_{k} R X_{i k}-\sum_{k} E X_{i k}^{(q-1)}\right) \frac{A i^{(q-1)}}{\sum_{k} R X_{i k}}+A i^{(q-1)}
$$

$A i \quad:$ ノード $i$ の発生交通量

$R X_{i k}:$ ノード $i$ から $k$ への実測道路区間交通量

$E X k i$ : ノード $i$ から $k$ への推定道路区間交通量

本研究では，道路区間交通量と交差点での右左折 直進交通量が観測值として与えられるため, OD交 通量の推計には，一般に観測䛊差および吸収マルコ フ連鎖における経路選択に関する誤差が含まれると 考えられる. しかし，ここではGAによる解の収束 性を検討するということで，GAの操作における誤 差を確かめることを目的としている.したがって， あらかじめ設定した発生交通量と分岐比率を用い, 吸収マルコフ連鎖によって道路区間交通量を算出し, それらの值をそれぞれ真実值（実測值）として取り 扱うこととする．具体的には，前述の $2 つ$ 方法に より推計された道路区間交通量および発生交通量に ついて, 残差平方和 (式 (3.1)) と重み付き標準比率 誤差(式(4.2))を用いて収束性の検討を行う.
表-1 GA及び逐次修正法の結果

\begin{tabular}{|c|c|c|c|c|c|c|c|c|}
\hline $\begin{array}{l}\text { 交 } \\
\text { 差 }\end{array}$ & $\begin{array}{l}\text { 交差 } \\
\text { 確率 }\end{array}$ & $\begin{array}{l}\text { 突然 } \\
\text { 変異 }\end{array}$ & $\begin{array}{c}\text { 世代 } \\
\text { (回数) }\end{array}$ & 9 & 10 & 11 & 12 & Z \\
\hline \multirow{6}{*}{1} & \multirow[t]{2}{*}{0.6} & 0.1 & $58 / 100$ & 10 & 50 & 98 & 501 & 2.5 \\
\hline & & 0.05 & $21 / 100$ & 11 & 51 & 95 & 496 & 40.5 \\
\hline & \multirow[t]{2}{*}{0.7} & 0.1 & $38 / 100$ & 7 & 54 & 78 & 505 & 352.9 \\
\hline & & 0.05 & $31 / 100$ & 7 & 51 & 97 & 499 & 18.4 \\
\hline & \multirow[t]{2}{*}{0.8} & 0.1 & $56 / 100$ & 8 & 48 & 127 & 497 & 625.6 \\
\hline & & 0.05 & $40 / 100$ & 16 & 27 & 127 & 480 & 1095.4 \\
\hline \multirow{6}{*}{2} & \multirow[t]{2}{*}{0.6} & 0.1 & $28 / 100$ & 11 & 49 & 97 & 498 & 15.4 \\
\hline & & 0.05 & $84 / 100$ & 12 & 48 & 96 & 497 & 30.7 \\
\hline & \multirow[t]{2}{*}{0.7} & 0.1 & $59 / 100$ & 12 & 48 & 97 & 497 & 24.9 \\
\hline & & 0.05 & $88 / 100$ & 12 & 50 & 100 & 493 & 51.5 \\
\hline & \multirow[t]{2}{*}{0.8} & 0.1 & $81 / 100$ & 8 & 48 & 99 & 505 & 17.6 \\
\hline & & 0.05 & $96 / 100$ & 12 & 49 & 101 & 489 & 111.7 \\
\hline & \multicolumn{2}{|c|}{ 逐次修正法 } & 147 & 11 & 50 & 100 & 501 & 3.7 \\
\hline
\end{tabular}

$\sqrt{\frac{1}{R_{X}} \sum_{i}^{m} \sum_{j}^{n} R X i_{j}\left(\frac{E X_{i j}-R X_{i j}}{R X_{i j}}\right)^{2}}$

\section{$R X_{i j} ：$ 道路区間交通量の実測值 \\ $E X_{i j}$ :道路区間交通量の推計値 \\ $R X \quad$ : 道路区間交通量の実測値の合計}

\section{(2) 結果と考察}

世代 (回数) と道路区間交通量の重み付き標準比率 誤差の関係を図-4 に示す。ここでの GAの操作条 件は \{ 交差 1 , 交差確率 0.6 以下, 突然変異確率 0.1 以下 $\}$ である. また, 収束時の発生交通量の推 計值と道路区間交通量の残差平方和を，表-1に示 す.

シミュレーションにおいて設定した各ノードの発 生交通量の真実值は， \{ノード $9=10$ ，ノード $10=$

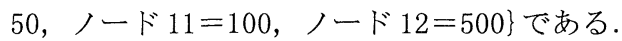

図-4よりGAを用いた場合，収束は非常に早く， 収束時の道路区間交通量の重み付き標準比率誤差も 小さいため，収束状態はよいといえる。

表-1 より，GAによる方法のうち，目的関数で ある道路区間交通量の残差平方和 $Z$ が最小であるの は，操作条件 \{交差 1 , 交差確率 0.6 以下，突然変 異確率 0.1 以下 $\}$ の場合であり，逐次修正法と比較 しても小さいということがわかる．しかし，交差方 法, 交差, 突然変異の確率によっては, 逐次修正法 よりも大きい值で収束している場合もある. 


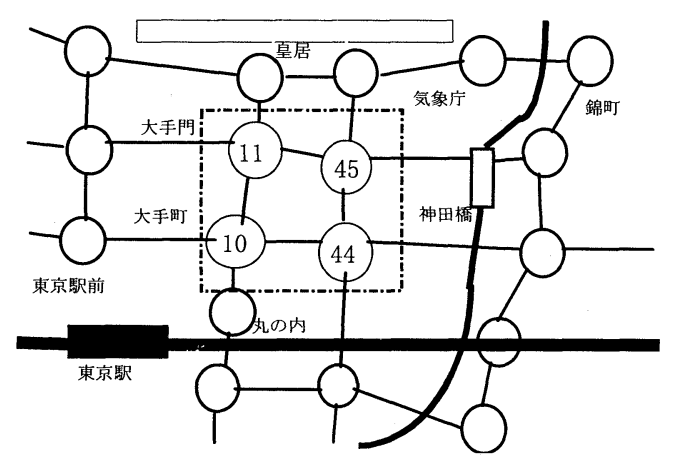

図-5 東京駅周辺の主要道路網

いずれにせよ，GAによる方法と逐次修正法のど ちらを用いた場合にも, 発生交通量として真実值に かなり近い值が与えられることがわかる.

以上より，GAを用いて発生交通量を与えた場合 解の唯一性は保証されないが, 真実值にかなり近い 值が得られており，したがってOD推計へのGAの 有用性が確認できたといえる. しかし, その操作条 件については，何種類かの場合について計算を行い, 評価関数のもつとも優れた条件を選択する必要があ るといえる.ここでは, 非常に小さな道路網を用い たため, 計算時間は，G A, 逐次修正法ともに約 5 秒であり差がみられなかった。推計精度, 計算時間 の比較のためにも，対象地域を拡大した場合の検討 も, 今後行っていく必要がある.

\section{G A を用いた簡易OD推計法の適用性}

\section{(1) O D推計法の手順}

東京駅周辺の主要交差点 (井型モデルに対応する 4 つの交差点, 図-5 における交差点番号 10,11 , 44，45）における分岐交通量の実測データ（朝・昼・ 夕の各 2 時間交通量) を用いて, 本推計法の適用性 を検討する. 図-5 に，ここで用いる交差点番号お よび道路区間番号を示す. また, 本推計法の適用に あたって，入力するデータは次の通りである.

(1)実測の道路区間交通量 (32 区間 : 既知)

右左折直進交通量の観測データを方向別に合計す ることによって得られる.

(2)対象地域外のノードからの発生交通量(既知)

過渡状態 $1 \sim 8$ から各交差点に流入する交通量 (道路区間 $1 \sim 8$ の交通量)をそのまま用いる. (3)遷移確率行列 (交差点での遷移確率 : 既知)

4 つの交差点における分岐比率 (各交差点で観測 された右左折直進交通量比率)により作成する.
（朝のデータによる）

○：1〜8の道路区間交通量

A：9〜16 の道路区間交通量

口 : 17〜32 の道路区間交通量 $Z=247834$

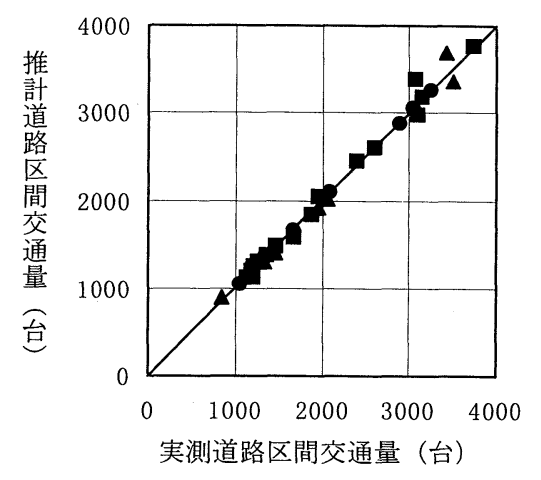

図-6 道路区間交通量の実績値と推計值の関係

(4)遷移確率行列 (交差点以外での遷移確率 : 仮定)

交差点以外での過渡状態から過渡状態への遷移確 率および過渡状態から吸収状態への遷移確率，また， 対象地域内ノードの発生状態から過渡状態への遷移 確率は未知であるので，それぞれ適宜仮定する.

また, 朝, 昼, 夕のそれぞれの時間帯では交差点 分岐比率に違いがみられ, 時間帯別にOD交通量が 異なると考えられる. そこで，朝・昼・夕それぞれ 2 時間の時間帯を対象にOD推計を行った. なお, G Aの適用に当たっては, 未知発生交通量のオー ダー(桁数) を最大 1000 程度に限定し, 乱数発生に より非現実的な值をとらないように配慮した。

\section{(2)結果と考察}

\section{a) 道路区間交通量の推計精度}

推計結果の一例を図-6 に示す.この図は朝の時 間帯における道路区間交通量の実測值と推計値の相 関を示したものである．また， $Z$ の值は残差平方和 の值を示している.この推計で仮定した交差点以外 での遷移確率は次の通りである.

交差点以外での過渡状態から過渡状態・・・0.9

過渡状態力ら吸収状態…… 0.1

対象外ノードの発生状態から吸収状態・・・0.5

図-6より, 観測データより得られる実績道路区 間交通量とマルコフモデルにより計算される推計道 路区間交通量の誤差はかなり小さいことがわかる. 
(朝のデータによる(変更後)）

○：1〜8の道路区間交通量

A：9〜16 の道路区間交通量

口 : 17 32 の道路区間交通量 $Z=52946$

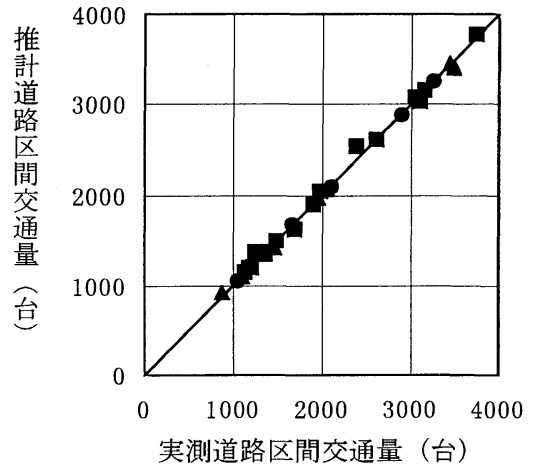

図-7＼cjkstart道路区間交通量の実績値と推計値の関係

表-2 道路区間交通量の推計精度

\begin{tabular}{|c|c|c|c|}
\hline 時間帯 & RM誤差 & $\begin{array}{c}\text { 重み付標隻 } \\
\text { 比率誤差 }\end{array}$ & 相関係数 \\
\hline 朝 & 0.204 & 0.039 & 0.995 \\
\hline 昼 & 0.230 & 0.042 & 0.993 \\
\hline 朝(変更後) & 0.144 & 0.023 & 0.999 \\
\hline
\end{tabular}

しかし， $\triangle$ の記号のなかに相関係数 $\mathrm{r}=1$ である直 線から離れた点を示しているものもある。この主な 原因としては，未知である対象地域内ノードへの吸 収確率を便宜的に，上記のように与えていることが 考えられる. そこで, 交差点分岐比率以外の遷移確 率を上記の配分結果を考慮して何通りか設定し, 再 計算を行った．その中で, 推計精度が向上した遷移 確率は次の通りである。（図-7）。

ノード(12) $\rightarrow$ 過渡期 $23 \cdots \cdots 0.4$

ノード(12) $\rightarrow$ 過渡期 $28 \cdots \cdots 0.6$ 過渡期 $18 \rightarrow$ ノド(10 …・. 0.2

これらの推計結果の精度を道路区間交通量の誤差 で示したのが表-2(RM誤差, 重み付標準比率誤差, 相関係数)である.

この結果，道路区間交通量の実測值と推計值の誤 差は非常に小さいことがわかる. しかも，直観的で はあるが遷移確率の未知要素を更新することにより， さらに推計誤差を小さくすることが可能である.
表-3 OD交通量の推計精度

\begin{tabular}{|c|c|c|}
\hline $\mathrm{RM}$ 誤差 & 重み付標準比較誤差 & 相関係数 \\
\hline 6.007 & 0.267 & 0.989 \\
\hline
\end{tabular}

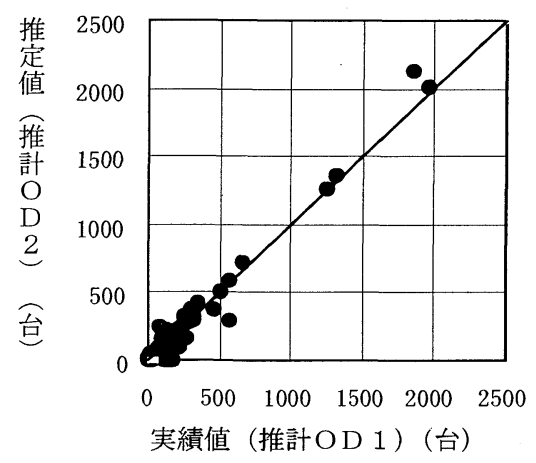

図-8 実績OD交通量(推計OD 1) と 推計OD交通量(推計OD 2)の関係

\section{b ) OD交通量の推計精度}

本研究で用いた観測データでは，実際のOD交通 量が不明であるため，道路区間交通量の推計誤差が 小さいとしても必ずしも推計された OD交通量が実 績(真実) OD交通量に近いという保証はない。そこ で，OD交通量の推計精度を次の手順で確かめる. (1)東京駅周辺における実測データ (道路区間交通量, 右左折直進交通量)を用いて推計された OD交通量 （推計OD 1) を，既存の交通量配分モデル(等時間 原則配分の近似解法である分割配分法をベースとし， 信号交差点を考慮した時間交通量配分モデル)によ り，各道路区間に配分する.

(2)配分結果 (道路区間配分交通量，右左折直進交通 量)を観測值とみなし，再びG A マルコフOD推計 モデル(交通量の配分には吸収マルコフ連鎖モデル を用いている)により OD交通量(推計OD 2) を推 計する.

(3)推計 O D 1 （実測データを用いて 1 次推計した実 績OD交通量) と推計OD 2 を比較する.

表-3 にOD交通量の推計精度 $(\mathrm{RM}$ 誤差，重み付 標準比率誤差，相関係数)を示す。 また，その相関 図を図-8に示す.

これらより, 道路区間交通量の精度と比較すれば, OD交通量の精度は多少低いが，相関係数も高く, 重み付標準比率誤差で $27 \%$ と比較的よい推計結果 であることがわかった。 
（1）交差点における○D遷移確率の変動特性分析

ここで提案する簡易 O D 推計モデルの適用に当 たっては，外生的に遷移確率行列を与える必要があ るが，一般に交差点での分岐比率は時間的に変化す るため，その変動特性を分析しておく必要がある. そこで本研究では以下に示す方法により分析を行っ た.

(i) 二項分布の母数 (比率) に関する検定

（正規分布による近似的な検定）

$$
z=\frac{\left(X_{i} / n\right)-P_{0}}{P_{0}\left(1-P_{0}\right) / n}
$$

$P_{0}:$ 比較対象の交差点分岐比率

( 2 時間あるいは 6 時間の分岐比率)

$X_{i}:$ 細かく区切った時間帯における右左折直進 のそれぞれの交通量

$n$ : その時間帯の交差点への流入交通量

時間帯ごとの交差点における分岐比率の変動特性 を調べるために，(1)，(2)の有意差検定を行った.

(1)朝・昼・夕の各 2 時間, 合計 6 時間の分岐比率と 朝・昼・夕それぞれ 2 時閒の分岐比率の有意差検定 (2)観測時間 2 時閒における交差点分岐比率とその 2 時間を 1 時間, 40 分, 30 分, 20 分, 10 分に区切っ た時間帯における分岐比率の有意差検定

(ii) OD分布の分布形に関する変動誤差分析

（重み付き標準比率誤差）

$$
\sqrt{\frac{1}{R T} \sum_{i}^{m} \sum_{j}^{n} R T_{i j}\left(\frac{T_{i j}-R T_{i j}}{R T_{i j}}\right)^{2}}
$$

$R T_{i j}$ : 比較対象の交差点 $\mathrm{OD}$ 交通量

（2 時間のOD交通量）

$T_{i j}$ : 細かく区切った時間帯における

交差点OD交通量 ( 2 時間の交通流率)

$R T \quad: \mathrm{OD}$ 交通量の合計值 $=\sum \sum R T_{i j}$

各交差点を中心とする十字型道路網を作成し，そ こで表される各方向ごとの交通量(交差点分岐交通 量）を各交差点におけるOD交通量と考え，その時 間帯ごとの変動特性を調べた。

具体的には, 東京駅周辺の主要交差点 (図-4, 交 差点番号 $10,11,44,45)$ における分岐交通量の実測 データ (朝・昼・タの各 2 時間を対象とした 10 分間 交通量データ)を利用した。

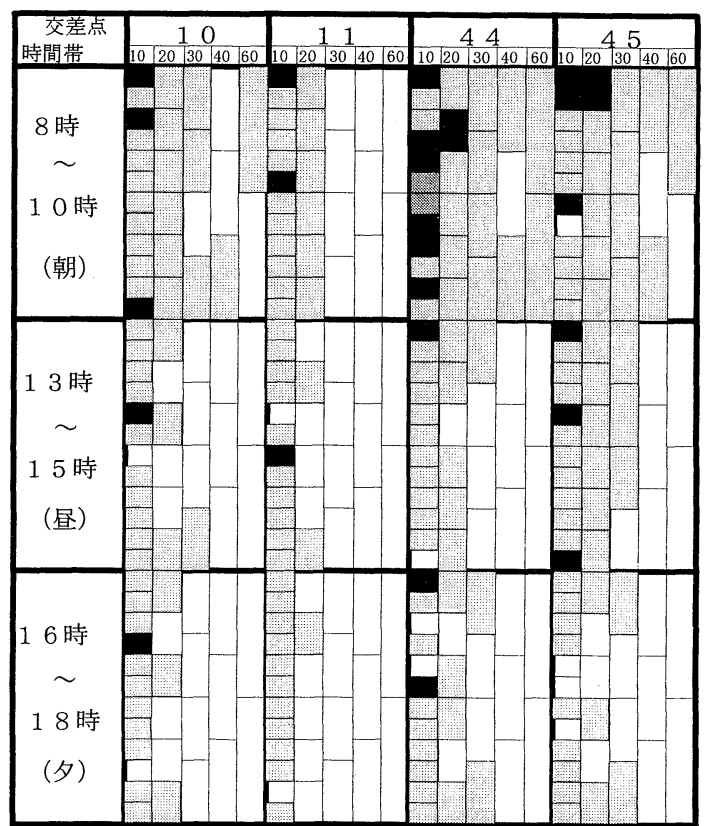

誤差が 0.100 以上のもの

誤差が 0.200 以上のもの

二項分布の交差点分岐比率に関する結果(有意差 検定(1)）から，6 時間全体と朝・量・夕の各 2 時間 の交差点分岐比率には有意な差(有意水準 $5 \%$ ) が見 られ，それぞれの時間帯で交差点の分岐比率に違い があることが明らかとなった。

表-4 は，細かく区切った各時間帯と 2 時間の交 差点OD交通量の分布形の違いを重み付き標準比率 誤差(相対誤差)で表したものである。ここでは，重 み付き標準比率誤差が 0.100 以上の時間帯に薄い網 掛け， 0.200 以上の時間帯に濃い網掛けを施した. この表より, 網掛けが現れるのは 30 分間隔より細 かく区切った場合である.したがって，ほぼ 40 分 間以上交差点分岐交通量を観測すれば，安定した分 岐比率が得られると考えられる．また，有意差検定 (2)の結果より，有意な差(有意水準 $5 \%$ ) があると認 められた区切りの数がその区切り全体に占める割合 を見ても，ほぼ同様な結果であった.

そこで，6. (2) では，2 時間データから与えられ る遷移確率を使って推計 $\mathrm{OD}$ 交通量を算出するとと もに, 30 分, 40 分閒データを使った場合の推計 $O$ $\mathrm{D}$ 交通量との相対誤差の比較分析を行う。つまり, 30 分間または 40 分間測定した右左折直進交通量か ら推定したOD遷移確率を使っても2 時閒のOD推 計が可能かどうかの検討を行う。 
(1)重み付き標準比率誤差

\begin{tabular}{|c|c|c|}
\hline \multirow{1}{*}{$8: 00$} & 30 分間隔 & 40 分間隔 \\
\cline { 2 - 3 } & 0.386 & 0.312 \\
\hline $0: 00$ & 0.122 & 0.112 \\
\hline 0.121 & 0.116 \\
\hline 0.123 & 0.116 \\
\hline $10: 00$ &
\end{tabular}

(2)相関係数

\begin{tabular}{|c|c|c|}
\hline \multirow{2}{*}{$8: 0$} & 30 分間隔 & 40 分間隔 \\
\hline & 0.9919 & 0.9942 \\
\hline \multirow{3}{*}{$9: 00$} & 0.9980 & \\
\hline & 0.9976 & 0.9909 \\
\hline & 0.9978 & 0.9985 \\
\hline
\end{tabular}

\section{（2）ＯD遷移確率の変動がO D交通量の推計精度に 及ぼす影響分析}

ここでは，朝の 2 時間データを用いた場合と， 30 分間データ (4 種類), 40 分間データ (3 種類) を用 いた場合の OD交通量の推計精度 (相対誤差) を比較 する. 分析結果を表-5 (重み付き標準比率誤差, 相 関係数)に示す.

2 時閒の各道路区間交通量と 30 分間または 40 分 間観測した右左折直進交通量で推計した場合と 2 時 間観測した右左折直進交通量を用いた場合と比べる と, 初めの時間帯を除けば, 全体として, 相関関係 も非常に高く，相対誤差も約 $12 \%$ と非常に小さい 結果となった。ただし, 初めの時間帯については, この 30〜40 分間だけが非常に異なった性質を持っ ていると考えられる.この具体的な理由としては, 8:30 頃までが通勤ラッシュのピークで, その後, 通勤人数が減少することが考えられる.したがって, 特に朝の時間帯について 40 分間データによって遷 移確率を与える場合, その特徵を考慮して適用寸る 時間帯を検討する必要がある，すなわち，そうする ことによって, 推計誤差をより小さくすることがで きると思われる. なお, 右左折直進交通量の観測時 間を 50 分， 60 分と長くすれば，当然のことながら さらに推計精度は向上する.

\section{7. まとめと今後の課題}

本研究は, 都市内のある限定された地域を対象と した新しい交通需要推計法 (簡易 OD推計法) を提案 し，その収束性を検討するとともに東京駅周辺の主

要交差点における実測データを利用して，その適用 性を検討したものである. 今回提案したモデルの特 徵は, 対象地域内の交差点において右左折直進交通 量の比率を観測しておくだけで，簡単にOD交通量 を推計できる点にある，すなわち，道路区間交通量 (交差点分岐比率)の観測データのみから OD交通量 の推計が可能である点が大きな特徵である.

本研究での結果をまとめると, 次のようになる. (1)交差点で観測できる右左折直進比率と道路区間交 通量を入カデータとして, 遺伝的アルゴリズム $(\mathrm{G}$ A）を組み込んだ吸収マルコフモデルを用いれば, 非常に手軽にOD交通量を推計できる.

(2)東京駅周辺における実測交通量データを用いた ケーススタディでは, 朝・昼・夕の各 2 時間の OD 交通量を推計するには, 各道路区間の 2 時間交通量 と各交差点の右左折直進交通量を $30 \sim 40$ 分間観測 すればほぼ十分であり，区間交通量のデータとして 車両感知器データが利用できれば, さらに手軽にO $\mathrm{D}$ 推計が可能である.

(3)対象地域における事前情報（マクロゾーン区分の 既存 OD交通量や土地利用状況を表す人口・経済指 標などのデータ)が全くない場合のＯD推計が可能 であり, その点では今後の実用性が期待できる.

ただし，OD交通量の推計精度には多少の誤差が 存在した. その原因としては, (1)仮定した経路選択 モデルが吸収マルコフ連鎖モデルであるため, 低い 確率ではあるが吸収されるまでに同じ経路を何度も 回ってしまう場合が生じるからである，今後は，マ ルコフモデルに改良を加え，非現実的な経路選択を 行わないようにしたい ${ }^{14)}$. また，(2)外生的に与える 遷移確率行列の中に未知要素が存在し, 今回はその 未知要素を適当に仮定したからである.この值は， 発生交通量に対し独立していないため, GAの設計 変数には加えることができない.したがって，今後 はそれらを合理的に決定する方法の確立が必要であ る。なお，今回のケーススタディーでは対象道路網 が小さく未知変数の数が少ないために, 非常に解の 収束性が速かった。今後は対象地域を広げ, GAの 収束性など本推計モデルの適用性（適用可能な対象 地域の広さや最適な交差点右左折直進比率の観測時 間間隔など)を検討する必要がある。

謝辞 : 最後に, 本研究は文部省科学研究費.一般研 究 C (代表 高山純一)，ならびに基盤研究 $\mathrm{B}$ (代表 名古屋工業大学教授 松井寛)により行った研究成果 の一部である.ここに記して感謝したい. 


\section{参考文献}

1）井上博司：交通量調査資料を用いたOD交通量の統 計的推計法, 土木学会論文集, 第 332 号, pp. 85～ 94, 1983.

2 ) 飯田恭敬, 高山純一, 金子信之 : 傾向変動を考慮し たリンク交通量によるOD交通量推計法, 土木学会 論文集，第 383 号，pp. 83〜91，1987.

3 ) 井上博司 : シャドウ・コスト概念による観測交通量 からのOD交通量推計法，土木学会論文集，第 401 号, pp. 41〜50, 1989.

4) 井上博司 : スクリーンライン調査によるOD表の精 度の検定およびOD表の修正法, 交通工学, Vol. 12, No. 6, pp. $11 \sim 19,1977$.

5) Van Zuylen, H. J. and Willumsen, L. G. : The Most Likely Trip Matrix Estimated from Traffic Counts, Transpn. Res.-B, Vol. 14B, pp. $281 \sim 293$, 1980.

6 ）松本幸正, 藤田素弘, 松井寛: リンク交通量に基づ く時間OD交通量の推計手法に関する研究, 交通工 学, Vol. 29, No. 3, pp. 11 19, 1994.

7 ）飯田恭敬，浅井加寿彦，椿川利弘：観測交通量によ る交通需要推計モデルの部分道路網結合計算法の検 討, 交通工学, Vol. 15, No. 6, pp. 21 31, 1979.

8 ) Norman, M. , Hoffmann, N. and Harding, F. :

Noninterative Methods for Generating A

Realistic Turning Flow Matrix for A Junction,

Traffic Engineering and Control, Vol.20, No. 12, pp. $587 \sim 589,1980$.
9 ）佐佐木綱：吸収マルコフ過程による交通流配分理論 土木学会論文報告集，第 121 号, pp. 21 32, 1965.

10）宮沢丈夫 : 遺伝的アルゴリズムと最適化問題，現代 科学の最先端, 1991.

11）田村亭, 杉本博之, 上前孝之：遺伝的アルゴリズムの 道路整備順位決定問題への適用，土木学会論文集， 第 482 号, pp. 37〜46, 1994.

12）飯田恭敬 : 発生交通量のみを変量とした実測交通量 による交通需要推計法, 土木学会論文報告集, 第 283 号, pp. 95 104, 1979.

13）財) 国土開発技術センター:平成 5 年度幹線道路一方 通行調査検討業務報告書, 1994 .

14）赤松隆：Markov 連鎖配分と LOGIT 型配分，土木学 会交通ネットワークスタディー資料，1995.

15）高山純一, 杉山智美, 藤岡寛之：GAを用いた吸収マ ルコフ連鎖による観測交通量からのOD推計法の適 用性，土木学会年次学術講演会概要集，pp. 142～ 143, 1995.

16）高山純一, 杉山智美, 藤岡寛之 : 交差点分岐比率の変 動が観測交通量からのOD推計に及ぼす影響分析, 第 15 回交通工学研究発表会論文報告集, pp. 221～ 224,1995

17）高山純一,杉山智美：GAを用いた観測交通量から のOD推計法の解の収束性，土木学会中部支部研究 発表会講演概要集, pp. 611〜 612, 1996.

（1996.8.13 受付）

\section{A STUDY ON O-D ESTIMATION MODEL BY OBSERVED LINK FLOWS USING ABSORBING MARKOV CHAIN}

\section{Jun-ichi TAKAYAMA and Tomomi SUGIYAMA}

In order to optimize signal control parameters and to reexamine traffic regulations on a particular aspect of the subject area, origin destination table must be estimated in detail. We present a simplified O-D estimation model from measurement of traffic flows on the links in road network by using Absorbing Markov Chain combined with Genetic Algorithm. We analyze the convergence of this model. And the model suggested here is applied to the practical network in the vicinity of Tokyo Station in order to reveal the properties of the modified model and to investigate the validity of this model. 